
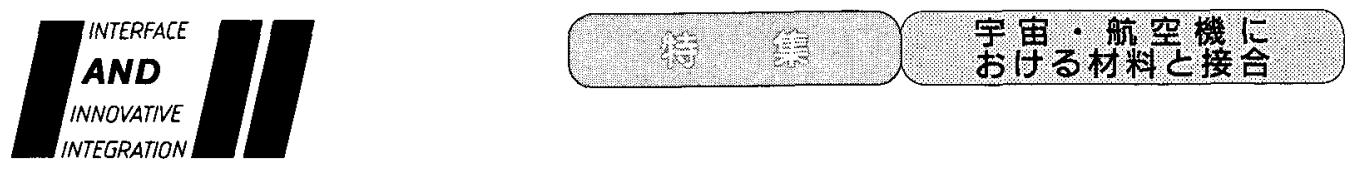

\title{
ロケットにおける材料と接合*
}

清 藤 晋 一 郎**

\section{Materials and Joining Technologies for Rocket Structures*}

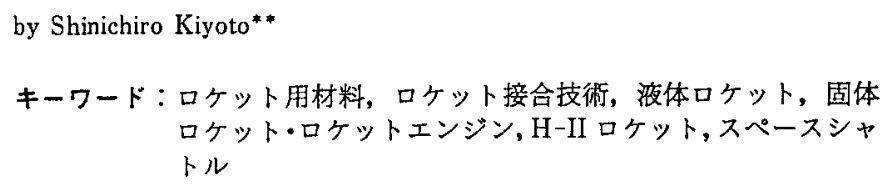

\section{1.はじめに}

1957 年 10 月 4 日ソ連の人工衛星スプートニク 1 号の打上げによって幕が開かれた宇宙開発は，最初 地球の低軌道への人工衛星打上げに始まり, 次いて 高度約 $35,800 \mathrm{Km}$ の静止軌道への打上げへと進み, さらに惑星探査へと広がった。 また，ロケットの大
型高性能化と共に有人宇宙飛行が可能となり，1969 年には米国のアポロ計画によって遂に人類は初めて 月面に着陸することができ,さらに 1981 年には米国 のスペースシャトルが飛行を開始して，宇宙空間へ の人と物の往復は格段と容易になった。

一方, 我が国においても，1955 年 4 月東京大学生 産技術研究所（現文部省宇宙科学研究所）は, 全長

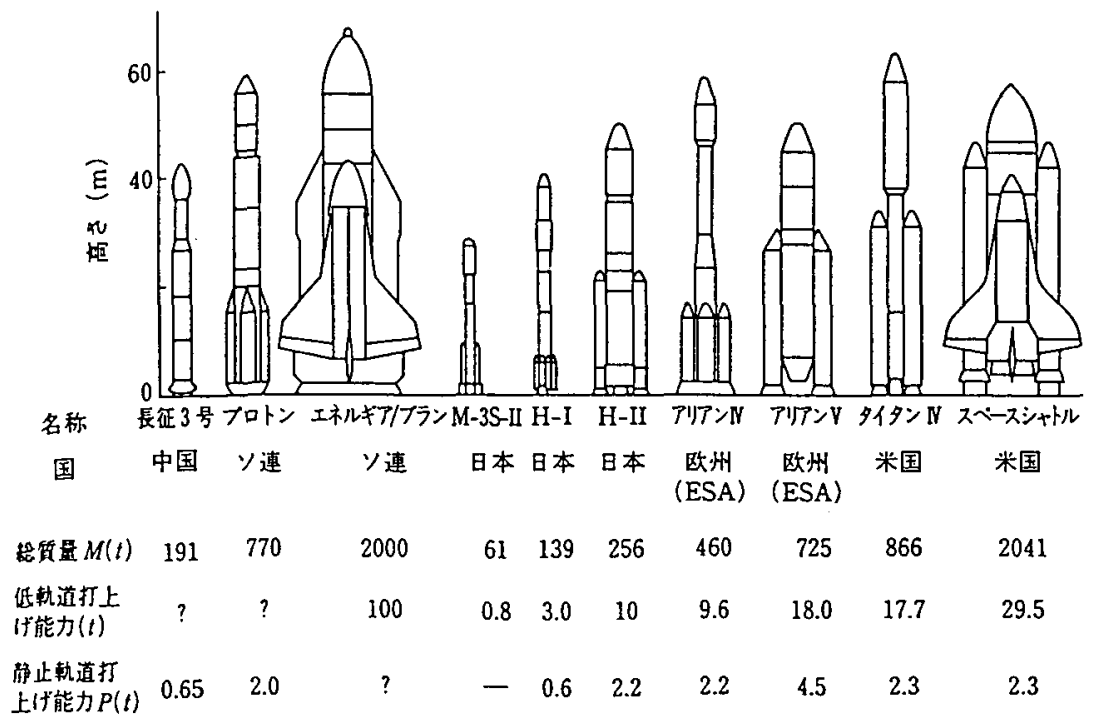

図 1 世界の主要ロケット 
$23 \mathrm{~cm}$ のペンシルロケットの水平発射試験に成功, これが日本のロケット開発の出発点となった。これ らロケットは, 開発初期には固体推進薬が用いられ, その後宇宙科学研究所を中心とする科学衛星打上げ 用ロケットにはこの固体ロケット技術が継承されて さたが，一方，大型実用衛星打上げ用ロケットは， 宇宙開発事業団の液体口ケット技術により N-I, NII, H-I ロケットの開発実用化が取り行なわれ，さら に現在 1994 年初頭の打上げを目指して, 液体水素/ 液体酸素を推進薬とする H-II ロケットの開発が鋭 意進められている状況にある。

これら内外の代表的ロケットは図 1 に示す通りで ある1.

本稿ではこれらロケット技術開発の動向をふま え，ロケット構造のなかで材料及び接合技術がいか なる適用現状にあり，かつ今後どのようなものが求 められているかを概説する.

\section{2. ロケットにおける材料技術}

ロケットはこれを軌道に乗せるためには毎秒 7.9 $\mathrm{Km}$ の第一宇宙速度へ加速する必要があるが，この ためには機体は質量比（ロケットの全体質量を構造 質量で除した值）が大きく，エンジンは推力比（推 進薬の噴出速度を重力加速度で除した值）が高いこ とが必要で, したがって構造材料には高比強度, 高 剛性が要求されると共に,製造加工性や品質信頼性, コスト等も重要な因子となる.

以下，液体ロケット機体，固体口ケット，ロケッ トエンジンの類別のもとに，ロケットにおける材料 技術の状況を述べる。

\section{1 液体ロケット譏体用材料}

液体口ケットにおける使用材料構成を H-II 口 ケットを例にとり図 2 に示す2．

液体ロケットにおいてはその原型であるドイツの V-2 は，外形を構成する外款構造の中に推進薬タン クを収納する様式を採っていたが，その後の液体口 ケットでは H-II 構造に示されるごとく, 推進薬夕 ンクが外殼構造体をも兼ねる様式となり，推進薬夕 ンクと段間構造それ自体で機体が構成される構造と なった。

推進薬タンクは発射時の全備重量の約 $90 \%$ 占 める液体燃料を収容する圧力容器であると共に，飛 行時の大きな加速度及び荷重に耐えねばならず，材 料には軽量化のための高い比強度と溶接構造による 十分の気密性が要求される。さらに極低温の液体水
素や液体酸素が推進薬として使用されるに至り, 低 温脆性の問題とも相まって，今日溶接可能な高力ア ルミニウム合金がその適用材料として主流となって 来ている。

推進薬タンク用高力アルミニウム合金としては, 米国では宇宙開発の初期にはレッドストーン等に溶 接性や耐熱性に優れた 6061 合金が使われたが,その 後,軽量化を図るためデル夕等では高強度の 2014 合 金が使用された。この合金は当時の溶接技術で可能 な最高強度を有していたが，しかし，応力腐食や補 修溶接など製造工程の安定性が重視され，また，推 進薬として液体水素の使用が拡がって極低温特性が ますます必要とされてきたところから，サターンや スペースシャトルでは 2219 合金が採用されるよう になり，現在に至っている。

我が国においても，開発着手当初の N-I ロケット では 2014 合金を使用していたが，溶接部応力腐食割 れの問題も経験し，その後の N-II, H-I, H-II では 米国と同樣に 2219 合金に変更し今日に至っている. なお，溶接性が良く強度も高い $\mathrm{Al}-\mathrm{Zn}-\mathrm{Mg}$ 系 3 元合 金 7020(AZ 5 G) も欧州のアリアンロケットでは使 用された実績をもっている。

一方, 段間構造は, エンジン, 電子機器などの䑶 装品を搭載すると共に，推進薬タンクと同しく飛行 時の荷重に耐える必要がある。この構造は航空機と 同様りベット結合が今なお主流で，材料も 2024,

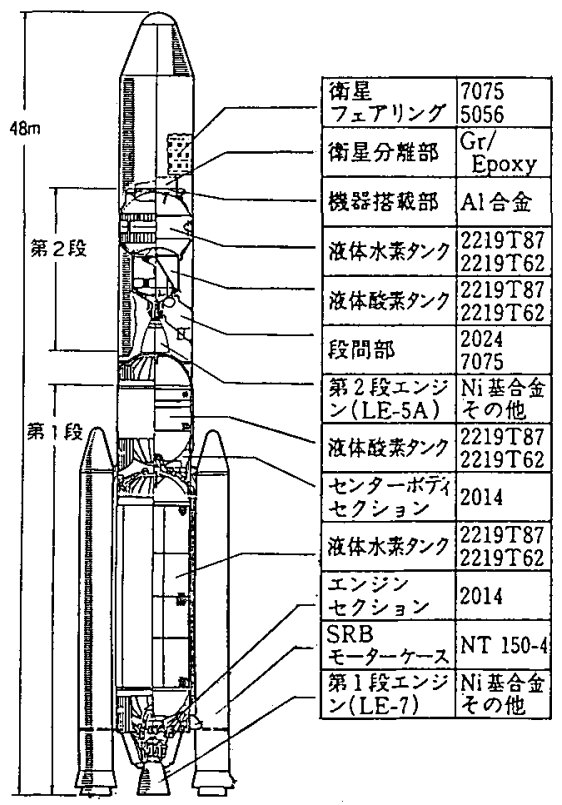

图 $2 \mathrm{H}-\mathrm{II}$ ロケットの主要構成材料 


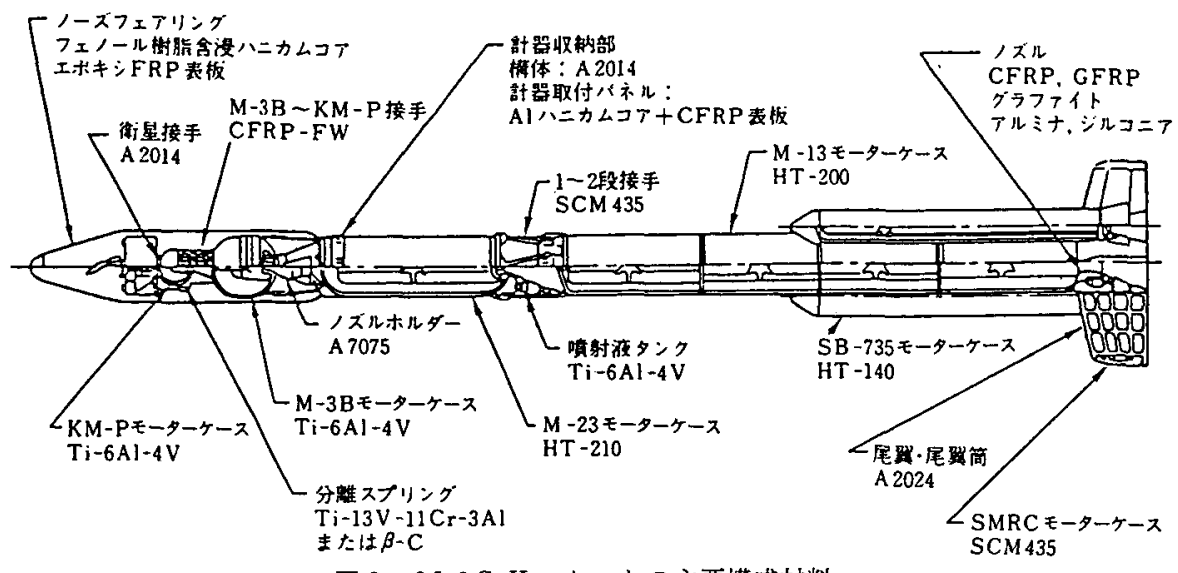

图 3 M-3 S-II ロケットの主要構成材料

7075 などの高力アルミニウム合金が多く使用され ているが, しかし今後この分野は CFRP 等の複合材 料の更なる進出が予想され，また，2324，7150 等の 改良合金やAL-Li 合金等も対象になってくるもの と考えられる。

ロケット機体用材料としては，その他推進薬を圧 送するための気蓄器等の高圧ガス容器として, 溶接 可能で靭性に優れ，かつ比強度の高いチタン合金が 多く使用されている.材質的には, Ti-6Al-4V や Ti$5 \mathrm{Al}-2.5 \mathrm{Sn}$ 等が中心て，極低温用については勒性の 点から不純物元素の少ないELI グレードが主と なっている．な扔チタン合金の圧力容器は従来は 鍛造萦材の機械加工により製作されていたが，ス ペースシャトルでは Ti-5 Al-2.5 Sn ELI の精密鋳 造品で造られており，また最近では板材からの超塑 性成形やより加工性の良い $\mathrm{Ti}-15 \mathrm{~V}-3 \mathrm{Cr}-3 \mathrm{Al}-$ $3 \mathrm{Sn}$ 等の $\beta$ - Ti 合金の使用による低コスト化も進ん できている.

\section{2 固体ロケット用材料}

固体口ケットは，固体状に固めた推進薬を点火燃 焼させ，発生する高温高圧の燃焼ガスを燃焼室の一 端に取付けたノズルから噴出させて推力を得るもの でここれは下段用ブースタとして使用される大型 のものから，上段用あるいは人工衛星の静止軌道投 入用のアポジモータのような小型高性能のものまで 各種あり，その材料は構造材料と耐熱材料とに大別 される。

固体ロケットにおける使用材料を, 宇宙科学研究 所の M-3 S-II ロケットを例にとり図 3 に示す3).

構造材料としては, 固体ロケットの機体構造であ ると共に，燃焼ガスの王力を保つ压力容器でもある モーターケース用材料が最も重要である，質量比を
高めるために高い比強度と破壊勒性をもった材料が 要求され，金属材料ではさらに溶接構造を採用し得 ることも必要で, 大型モーターケース等には高張力 鋼の使用が多い，その他，小型のロケットでは FW (Filament Winding) 法による FRP 製やチタン合金 製のものも用いられている.

使用される高張力鋼として一般的なものは, AISI- 4130 やAISI- 4132 等の Cr-Mo 鎡で, これら はミューロケットやNロケットの補助ブースタに 使用された。 また，さらに高強度が要求されるモー ターケースには, AISI-4340 やD 6 AC 等の Ni-CrMo 鋼が $1.3 \sim 1.6 \mathrm{GPa}$ の強度に熱処理されて使用 されるが，これらの材料は炭素量が 0.35 0.45\%と 比較的多くこのため溶接割れ感受性が高いという 難点もある。また，9 Ni-4 Co 鋼をべースとして開 発されたベーナイト鋼 HT 140 N, NT-150, HT 230 等は, $1.5 \mathrm{GPa}$ レベルの強度を有し,その溶接性は良 好で，調質材のままで 100\%近い継手効率が得られ るが、これらは H-II ロケットの補助ブースタやM$3 \mathrm{~S}-\mathrm{V}$ ロケットの第 1, 2 段モーターケース等に使用 された。

一方，固体ロケット用耐熱材料としては，3,000 $\mathrm{C}$ に達する高温, 高圧, 高速の燃焼ガスにさらされる ノズル材料にグラファイトや CFRP, GFRP 等が, 耐熱というよりは樹脂が熱分解して炭化する際の吸 熱および生成ガスによる断熱効果を利用して，主構 造材への熱伝達を隇らすアブレーション材料として 主に用いられており，また，その他カーボン・カー ボン複合材も多く使用されている。

\section{3 ロケットエンシン用材料}

ロケットエンジンの構造材料は, 燃焼ガスの高温 に耐えると共に，推進薬によっては極低温の環境に 


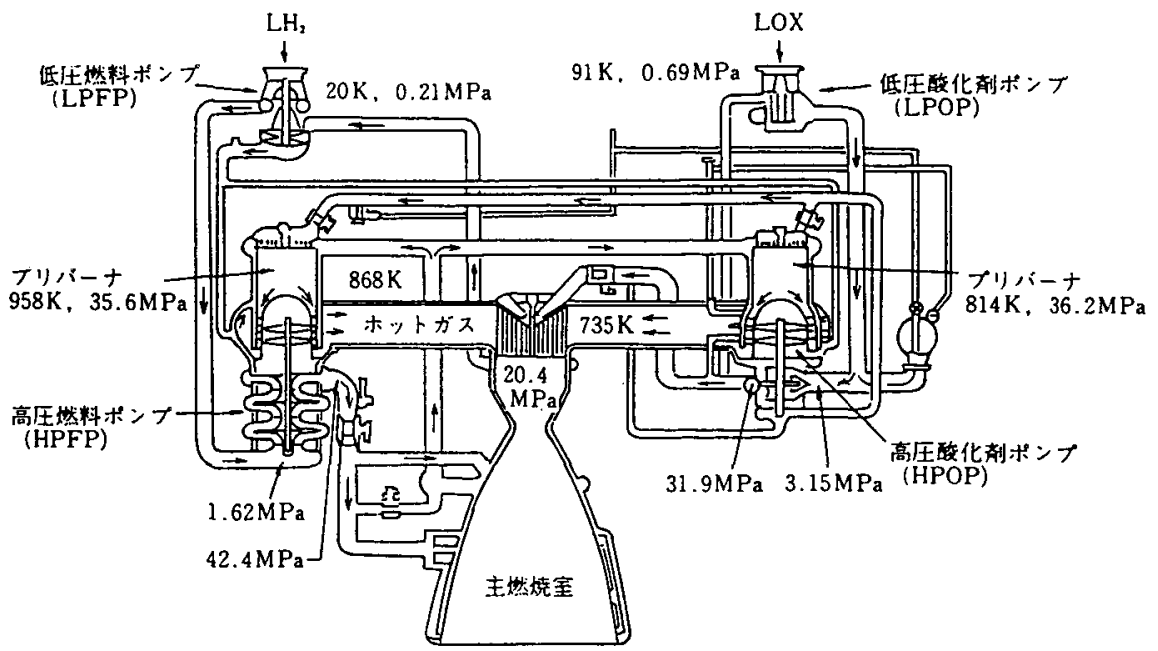

図 4 SSME系統図

表 1 SSME の主要棈成材料

\begin{tabular}{|c|c|}
\hline 材 料 & 遥用部位 \\
\hline $\begin{array}{l}\text { Inconel } 718 \\
\text { Inconel } 625\end{array}$ & 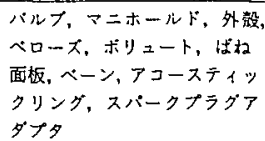 \\
\hline René 41 & ボルト，スクリュ \\
\hline K-Monel & $\begin{array}{l}\text { ターホホホンフステータおよU } \\
\text { ロータ, ハウシングがー }\end{array}$ \\
\hline MAR M216(DS) & タービン高 \\
\hline MAR M246(CC) & タービンノズル翼 \\
\hline Waspaloy & ティスク,シャフト \\
\hline Incoloy 903 & $\begin{array}{l}\text { ダクト,タービンハウジンク } \\
\text { ストラットリング }\end{array}$ \\
\hline A 286 & ノスルチューフ \\
\hline オーステナイト系 & シール, 熱交換器チニープ, ガ \\
\hline ステンレス铜 & スケット、リジメッシュ \\
\hline 440Cステンレス艄 & スラスト軸受，バルブシート \\
\hline $2024 \mathrm{Al}$ & リテーナリンタ \\
\hline 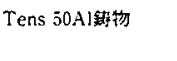 & 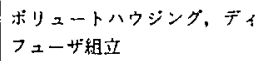 \\
\hline NARIOYZ & 燃娭空内简 \\
\hline ベリリウム筒 & 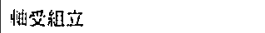 \\
\hline$T i-6 A l-6 V-2 S n$ & ジンバル栍投むょびリング \\
\hline$T i-6 A 1-4 V$ & $\begin{array}{l}\text { アクチュエータストラット. } \\
\text { マニホールド }\end{array}$ \\
\hline $7 \because-5 A 1-2.5 \sin$ & インベラ, バルオ \\
\hline$\Lambda g-8 C u$ & シール \\
\hline $\mid 7-4111$ & 纰塄 \\
\hline
\end{tabular}

耐えることも，また使用箇所によっては腐食性の燃 焼ガスに耐えることも要求される。

液体ロケットエンジンは, 航空機用ガスタービン に比べ，極めて短時間に最大出力運転を行うという 特徵があり, 従って材料的にも疲労やクリープ強度 より耐熱衝撃特性などが特に重要になる。また，強 制冷却構造の採用にともない, 耐熱性や熱伝導性も 材料には要求され，このため，これらの条件を満た す材料として, Inconel 718 等のニッケル合金や, そ の他超合金, ステンレス鋼, 高力チタン合金, 高熱
伝導性銅合金などが主要材料として多用されてい る。

なお，液体水素エンジンはその材料選定において は水素環境脆化の問題を配慮する必要がある. 水菜 環境脆化は液体水素を推進薬とするエンジンで，金 属材料が高圧水素ガス中で塑性変形を受けた際に生 じる脆化現象であるが，これについては，スペース シャトルの主エンジン(SSME)を開発した米国を中 心に研究が行われ，その結果，二ッケル基超合金， ステンレス鋼, マルテンサイト系高張力鋼, コバル 卜合金, チタン合金などの材料が高い水素環境脆化 感受性を示す一方,オーステナイト系ステンレス鋼, 銅合金, アルミニウム合金等はその感受性が低いこ とが確認され，この成果は現在もロケットエンジン 設計上の主要な指針となっている。

図 4 及び表 1 は, SSME の系統図と使用されてい る主要材料を示すものであるいが,我が国で現在開 発中の H-II ロケットの主エンジンである LE-7て も SSME と同じく 2 段燃焼サイクルが採用されて, 真空中推力約 $1.2 \mathrm{MN}$, 燃焼圧約 $15 \mathrm{MPa}$ が設計值 として計画されている。

\section{3. ロケットにおける接合技術}

ロケット製造技術の中核をなす接合技術としては ティグ溶接（GTA）を主体に，その他ミグ溶接 (GMA)，電子ピーム溶接 (EBW)，ろう付，拡散 接合等があるが,これらは高度に最適化されて各種 コンポーネントの接合に適用されている.

以下，ロケット機体，ロケットエンジンの類別の 


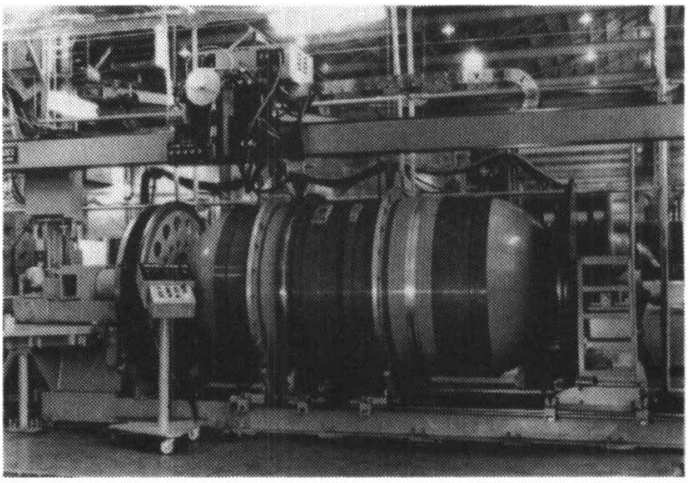

図 5 N-I 第 2 段タンクの溶接組立

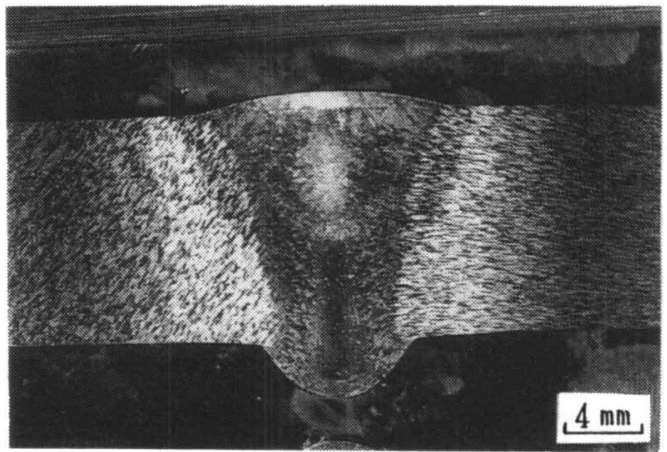

図 6 溶接部断面組織

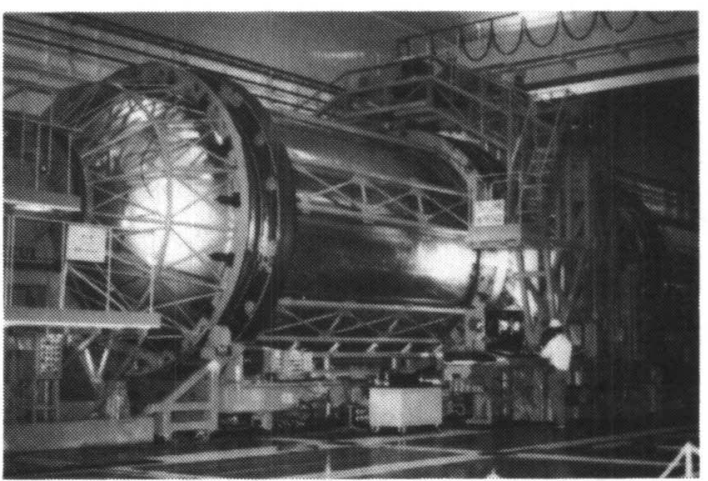

図 7 H-II 第 1 段タンクの溶接組立

もとに,ロケットにおける接合技術の状況を述べる。

\section{1 ロケット機体の接合技術}

ロケット機体においては, 液体ロケット推進薬夕 ンクが最大の溶接構造物となる.

我が国における液体ロケット推進薬タンクの本格 的開発は, 昭和 46 年 N-I ロケット第 2 段タンクよ り始まった。

本タンクの溶接状況は図 5 に示す通り, 直径は 1.4 $\mathrm{m}$, 溶接結合による共通隔壁式のモノコック・インテ グラル・タンク構造で, 材質としては高力アルミニ ウム 2014 合金鍛造材が使用された.溶接部板厚は約

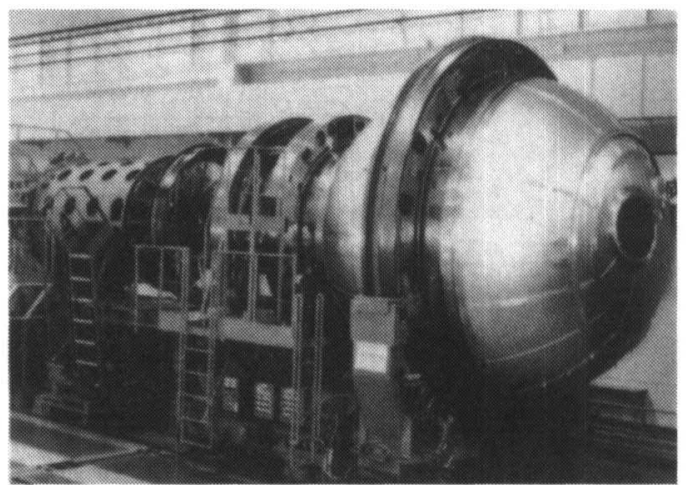

図 8 H-II 第 2 段タンクの溶接組立
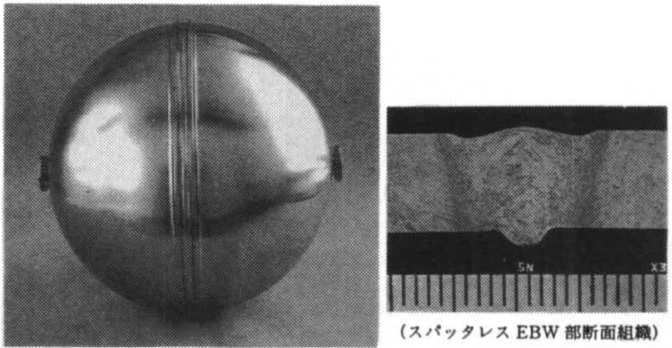

図 9 H-II 極低温ヘリウム気蓄器

$11 \mathrm{~mm}$, 溶接法としては, 当時我が国において初め て高力アルミニウム合金大型構造物に対してGTADCSP (直流正極性ティグ溶接) を採用，溶接開先は I 形突合わせとし, 裏波溶接による開先母材部の溶 融パスと溶接ワイヤを印加するフィラーパスの 2 層 溶接で溶接ビードは形成され，またアーク電圧を 10 $\mathrm{V}$ 程度にまで下げて，ほとんどゼロギャップ，うも れアーク状態とし，これに高周波電流や磁気擋汼を 重畳して溶接は行われた。溶接部断面組織は図 6 に 示される通りであるが, GTA-DCSP の採用により 溶接熱影響や歪の発生は小さく，かつ深溶込み特性 の高品質溶接が実現されだ5.

なお, 以降の N-II, H-I ロケットにおいても, 基 本的にはCTA-DCSP が主溶接法として採用され, あわせて一部の継手に対してはGMA-DCRP（直流 逆極性ミグ溶接）や $\mathrm{EBW}$ も適用された。

H-II ロケットは, 2 トンの衛星を静止軌道に投入 する能力をもつ我が国の次期主力ロケットで, H-I までに蓄積された技術をもとに, 純国産, 高信頼性, 低コストを目指して現在開発が進められている。

H-II ロケット全体構成は図 2 に示した通りであ るが, 本ロケットでは第 1 段, 第 2 段いずれとも液 体水素/液体酸素の極低温推進薬が全面的に使用さ れ，またタンク直径は $4 \mathrm{~m}$ に大型化している.第 1 


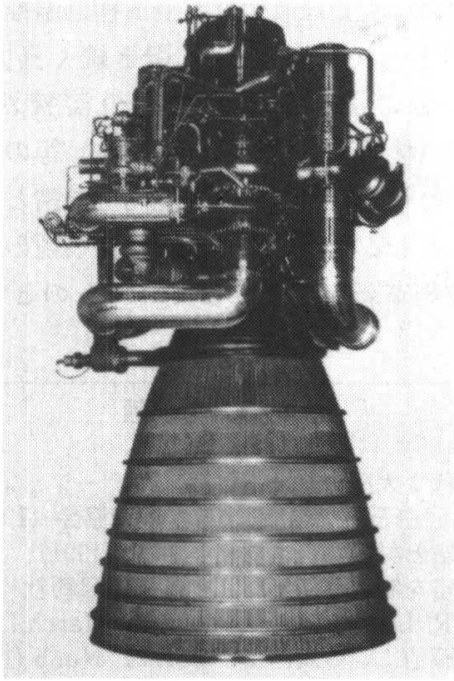

図 10 LE-7 エンジン

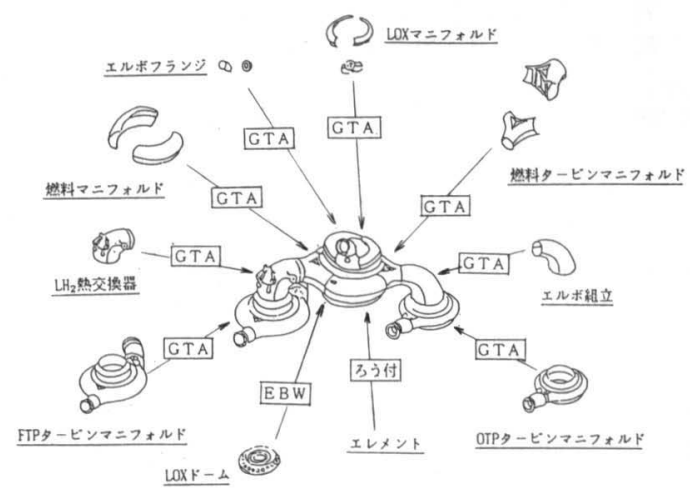

図 11 LE-7 主噴射器近傍の溶接組立

段タンクは, 液体水素/液体酸素の各タンクが分離し たセミモノコック溶接結合の分割型構造を採用, シ リンダは円周方向に 5 分割され, 機械加工, 曲げ成 形された 2219 板材でこれを構成,またドームは 8 分 割し, 化学的に減肉加工されたオレンジピールと キャップで構成され, そしてこれらは図 7 に示すご とく突合わせ溶接され，タンクは組立てられる。一 方, 第 2 段タンクは, 図 8 に示すごとく液体水素と 液体酸素の各タンクが真空断熱式共通隔壁を介して 溶接結合される。なお，これらに対する溶接技術は 基本的に H-I ロケットまでに確立したものの延長 線上にあるが，ロケットの大型化や継手の多様化， 製造コストの低減等の要請に伴い, CNC 全自動制御 溶接の採用や, 溶接前処理, 清浄度管理等との関連 から, GTA-DCSP に極く短時間 DCRP（直流逆極 性)成分を入れて開先クリーニング効果を得るなど, 種々の溶接技術の高度化も計られた 語. $^{6 .}$.
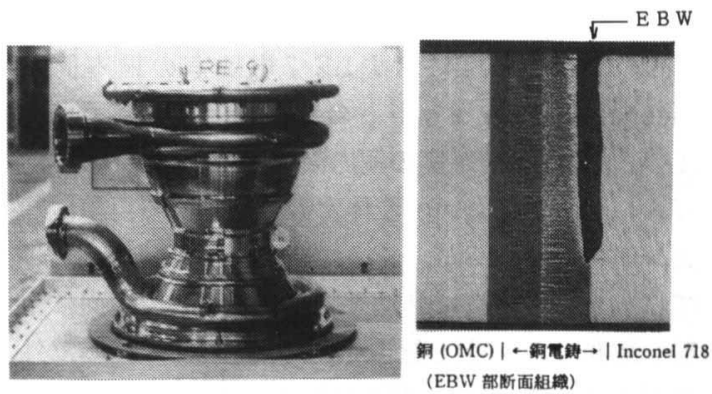

図 $12 \mathrm{LE}-7$ 燃焼室

FBW は図 9 に示す H-II ロケットの極低温ヘリ ウム気蓄器の溶接組立等に適用されている. 材料は 極低温にさらされることから Ti-6Al-4V ELI が選 定され, また溶接は気蓄器内部の清浄度管理の面か ら，スパッタの発生を防止するデフォーカス $\mathrm{EBW}$ が採用された7).

\section{2 ロケットエンジンの接合技術}

スペースシャトルの主エンジン SSME(図 4)にお いては主要接合技術として, 溶接法としてはGTA と $\mathrm{EBW}$ が，ろう付法としては貴金属ろうを用いた 炉中ろう付がもっぱら採用され, またその他構造メ ンバーの接合成形法として電鋳法が冷却溝構造の製 作に適用されている.

図 10 に示す我が国の H-II ロケット第 1 段主エ ンジンである LE-7 でも類似の接合加工技術が採用 される.

図 11 はこのうち, 主噴射器近傍の組立工程概要て あるが, 使用材料である Inconel 718 に対し, 溶接法 としてはGTA が広範に適用されている8

また, 高温ろう付は, ノズルスカート, 燃焼器, 噴射器などの耐熱合金のろう付組立に多用されてい る.な扔高温ろう付は, 一般には水素や真空雾囲気 の炉中ろう付が適用されるが, LE-7では, ろう付雾 囲気の清浄度を高め, かつ, ろう材や母材に含まれ る $\mathrm{Ag}, \mathrm{Cu}, \mathrm{Mn}$ など蒸気圧の高い元素の蒸発を抑制 し高品位のろう付品質を確保する目的で, 真空中へ 高純度のアルゴンガスを連続的に導入し, 流量およ び内圧を制御する,いわゆる真空一不活性ガス雾囲気 制御方式のろう付法が適用された. 図 10 に示すLE7 エンジンのノズルスカートは, 本方式によるろう 付で製作されたものであるが, スカートの直径は最 大部で約 $1.8 \mathrm{~m}$, 高さは約 $1.9 \mathrm{~m} て$, ろう材は $\mathrm{Ag}^{-}$ $\mathrm{Cu}-\mathrm{Pd}$ 系が用いられ, また, ろう付炉内圧は, 温度 サイクルに対応させて, 高真空から 40 Torr まで数 
段階に変えて制御された。

EBW は，図 12 に示す LE-7 燃焼室の鉰内筒と

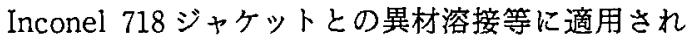
ている.なお, 燃焼室の銅内筒内壁は $3,000^{\circ} \mathrm{C}$ の燃焼 ガスにさらされため, 液体水素で泠却する再生冷却 方式が用いられるが，このための冷却溝製作法とし ては，銅合金の溝にワックスを充填，その表面に銀 粉を塗布して導電性を与え，次いでめっき槽内で外 表面全体に約 $10 \mathrm{~mm}$ 厚さに銅めつきした後,ワック スを溶出して冷却瑇を作る電鋳法が採用されてい Ђ.

なおその他，チタン合金製インペラーは拡散接合 を用いて製作されており，また，小型の菠体水素/夜 体酸素エンジンの燃焼器の製作には, インサート材 を用いた拹散接合も適用された9!。

\section{4. まとめ}

以上, ロケット構造における材料及ざ接合技術の 動向を概観した。

ロケット技術発展の過程は，まさに材料技術や接 合技術の進展の歴史と軌を同じにしている。米国等
ではすでに，例えば液体ロケット極低温推進薬タン ク用材料として 2219 合金に引き続く高力溶接用 $\mathrm{Al}-\mathrm{Li}$ 合金の開発や,またその溶接法として VPPAW（極性変換プラスマ溶接法）等の開発も進 んできており，ロケットの性能向上要請とも相まっ て, 今後ともこれら材料および接合技術の分野で, 新たな技術革新が展開されていくものと考えられ 万.

\section{考文 献}

1) 五代：大型ロケットと宇宙ステーション開発（第 15 回白石記念講座)，日本鉄鋼協会 (1988)

2) 宇宙と材料，日本材料学会編（1991）

3）宇宙を制する新素材，化学工業日報社（1988）

4) J. R. Lewis: Metal Progress, March (1985)

5) 清藤他：軽金属溶接，Vol. 21, No. 5 (1983), I

6) 清藤：溶接学会平成 3 年度春期全国大会フォーラ 么講演概要集, (1991)

7) 坂本：溶接技術, Vol. 37, No. 11 (1989), 87

8）橋本他：日本航空宇宙学会誌, Vol. 41, No. 474 (1993), 391

9）大村他：溶接学会誌, Vol. 59, No. 6 (1990), 67 